\title{
Redaksioneel
}

\section{By geleentheid van die 60ste verjaardag van prof AD Pont (21 September 1987) en prof JP Oberholzer (3 Oktober 1987)}

\section{ONTVANGERS VAN DIE HCM FOURIE-EREPENNING}

Prof AD Pont is reeds dertig jaar professor en hoof van die Departement Kerkgeskiedenis (Afd A) aan die Universiteit van Pretoria. Prof JP (Bart) Oberholzer is in 1971 benoem as professor en hoof van die Departement Ou-Testamentiese Wetenskap en dien sedert 9 Oktober 1987 as dekaan van die Fakulteit Teologie (Afd A), Universiteit van Pretoria. Hulle is onderskeidelik gebore op 21 September 1927 en 3 Oktober 1927. Albei hoogleraars is by twee verskillende geleenthede vereer deur die Kuratorium vir die Teologiese Opleiding van die Nederduitsch Hervormde Kerk toe die HCM Fourie-erepenning aan hulle oorhandig is. Dié erepenning word toegeken uit erkentlikheid vir hoogstaande kerklike en akademiese arbeid. Die redaksie van die Hervormde Teologiese Studies publiseer uit dankbare erkentenis, by geleentheid van die sestigste verjaardag van professor Pont and professor Oberholzer, die inhoud van die oorkondes wat onderskeidelik op 12 Mei 1986 tydens die een en sestigste en op 7 Mei 1983 tydens die sestigste Algemene Kerkvergadering van die Nederduitsch Hervormde Kerk van Afrika namens die Kuratorium aan hulle oorhandig is.

Studente van proff Pont en Oberholzer het bydraes vir die betrokke Aflewering van die Hervormde Teologiese Studies gelewer. Die redaksie is hulle dank verskuldig.

\section{ADRIANUS DROST PONT - M A, B D (UP), D Theol (UTRECHT)}

Adrianus Drost Pont, gebore op 21 September 1927, matrikuleer in die eerste klas aan die Afrikaanse Hoër Seunskool, Pretoria in 1943. Hy verkry die grade B A (met lof, 1946), B D (1949) en M A [Grieks] (met lof, 1952) aan die Universiteit van Pretoria, waar hy in 1951 voorsitter van die VSR is en die Abe Bailey Reisbeurs ontvang. In 1955 ontvang hy die 
graad D Theol van die Ryksuniversiteit van Utrecht met die proefskrif 'Nicolaas Jacobus van Warmelo'. Na 'n kort verblyf in die Gemeente Elsburg word hy op 1 Februarie 1957 hoogleraar in Kerkgeskiedenis en Kerkreg aan die Universiteit van Pretoria.

Prof Pont het oor die hele tydperk van sy akademiese loopbaan volgehou met publikasies van hoogstaande gehalte op die gebied van die kerkgeskiedenis, die kerkreg en die teologiese strominge van ons tyd. Met kritiese insig en vakkundige bedrewenheid het hy ' $n$ positiewe bydrae gelewer tot die bestendiging en uitbouing van die Bybels-Reformatoriese teologie. Sy leidende betrokkenheid by 'n jaarlikse Calvynkongres in Suid-Afrika en deelname aan die Internasionale Calvynkongres, sy veelsydige aktiwiteite ten opsigte van optredes voor kerklike gehore, memoranda, adviese en lidmaatskap van verenigings het hom ' $n$ faktor van blywende invloed op teologiese gebied gemaak. Deur sy bemoeienis is die Kerkhistoriese Genootskap gestig en onder sy leiding verrig dié vereniging steeds waardevolle arbeid op die gebied van die vroeëre en eietydse kerkgeskiedenis.

Prof Pont het as gereelde prediker en pastor in verskillende gemeentes, as lid en/of voorsitter van verskillende kerklike liggame, waaronder die Kommissie van die Algemene Kerkvergadering, die Raad vir die Argiefbewaarplek en Museum, die Raad vir Regsadvies, die Raad vir Barmhartigheidsdiens, die Raad vir Belydenis en Liturgiese Geskrifte, deur middel van kerklike adviese en talle geskrifte besondere diens aan die Kerk bewys; ook het hy vanweë sy besonder kritiese ingesteldheid die kerklike beraadslagings steeds opgeskerp en tot die keper gebring.

Die loopbaan van prof Pont word gekenmerk deur lewendige en aktiewe betrokkenheid op kulturele en soms ook politieke gebied, wat hom 'n wyle 'n omstrede figuur gemaak het. Sy besondere piëteit teenoor Kerk en volk het daardeur aan diepte gewen, en die Kerk het gebaat by die rypheid wat deur ervaring gekom het. Sy betrokkenheid by die Volkskongres oor die Kommunisme, die Christelike Kultuuraksie en etlike ander organisasies getuig van onvermoeide ywer vir sy oortuigings.

Uit die vaardige pen van prof Pont het die volgende selfstandige publikasies verskyn:

Nicolaas Jacobus van Warmelo 1835-1892; Die Nederduitsch Hervormde Gemeente Waterberg 1865-1965; Die Nederduitsch Hervormde Gemeente Heidelberg 1865-1965; Die oudste kerkgebou in Transvaal: Iets oor die geskiedenis van die kerkgebou van die NH Gemeente Potchefstroom 1866-1966; 'n Oorsig van die algemene 
kerkgeskiedenis en die geskiedenis van die Nederduitsch Hervormde Kerk van Afrika: Opgestel ten dienste van die kategese van die Kerk; Die historiese agtergronde van ons Kerklike Reg, Deel I.

Naas bogenoemde het hy tot op datum [12 Mei 1986] 40 artikels in die Hervormde Teologiese Studies gepubliseer, ongeveer 30 in Die Hervormer, 15 in Die Almanak, asook 'n hele reeks artikels in ander tydskryfte. Hy was redakteur en medewerker van verskeie publikasies. [Sedertdien is nog 4 wetenskaplike artikels in die Hervormde Teologiese Studies gepubliseer.] Verder is daar 'n reeks van memoranda en rapporte vir die Kommissie van die Algemene Kerkvergadering, die Raad vir Regsadvies en ander kerklike rade en liggame wat nie gepubliseer is nie. Talle referate, lesings en toesprake is gehou oor 'n reeks van onderwerpe by ringsaamtrekke van kerklike ampsdraers, asook kultuurbyeenkomste.

Daar is net een AD Pont in die Nederduitsch Hervormde Kerk. Die toekenning van die HCM Fourie-Erepenning aan hom gee onder andere daaraan uitdrukking. Naas sy sterk akademiese bydrae het hy op die identiteit en groei van die Nederduitsch Hervormde Kerk 'n besondere stempel afgedruk.

\section{JOHANNES PETRUS OBERHOLZER - M A, DD (UP)}

Johannes Petrus Oberholzer is gebore op 3 Oktober 1927 en groei op op die Oos-Transvaalse hoëveld, waar hy aan 'n klein plaasskooltjie standerd 6 slaag en daarna apn die Hoogenhout Hoërskool op Bethal in die eerste klas matrikuleer. Sy universiteitsopleiding ontvang hy aan die Universiteit van Pretoria. Nadat hy sy studie vir die BA- en BD-grade afgehandel het, word hy predikant in die Nederduitsch Hervormde Kerk met as eerste standplaas die Salisbury-kombinasie in die destydse Suid-Rhodesië, 'n kombinasie wat die hele oostelike helfte van die land beslaan het. Daarna het hy agtereenvolgens die gemeentes Boksburg, Middelburg Transvaal, Rustenburg, Pretoria en Verwoerdburg bedien. Intussen gaan hy voort met studie en ontvang die M A-graad in Semitiese Tale in 1957 en die DD-graad met lof in 1967. Oor die jare 1955-1958 is hy tydelik-deeltydse dosent in Hebreeus aan die Universiteit van Pretoria en in 1958 neem hy die Ou-Testamentiese deel van die pas ingestelde vak Bybelkunde aan die Universiteit van Pretoria waar asook in die jare 1968-1971. Hy neem ook die lesings in die Ou-Testamentiese Wetenskap waar tydens lang verlof en siekteverlof van prof dr ES Mulder. Vanaf 1 Januarie 1971 is hy hoof van en 
professor in die Departement Ou-Testamentiese Wetenskap in die Fakulteit Teologie (Afd A) aan die Universiteit van Pretoria, en vanaf 10 Oktober 1978 ook plaasvervangende dekaan van die Fakulteit. [Prof Oberholzer dien sedert 9 Oktober 1987 as dekaan.]

Op kerklike gebied is daar reeds verantwoordelikheid in wyer verband op hom geplaas. Hy is agtereenvolgens skriba van die ringe van Rhodesië, Germiston en Rustenburg. In Desember 1960 is hy lid van die afvaardiging van die Nederduitsch Hervormde Kerk na die beraadslaging tussen Suid-Afrikaanse lidkerke van die Wêreldraad van Kerke in Johannesburg (die 'Cottesloe-byeenkoms'), in 1961 word hy verkies as lid van die Kuratorium vir die Teologiese Opleiding en in 1963 as voorsitter van dié liggaam. In 1964 word hy lid van die moderamen en die Kommissie van die Algemene Kerkvergadering waar hy agtereenvolgens as vise-skriba en vise-voorsitter dien totdat hy in 1974 verkies word as voorsitter van die Algemene Kerkvergadering, 'n posisie wat hy tans nog beklee. In dié hoedanigheid is hy ook betrokke by ' $n$ verskeidenheid van kerklike liggame .

In 1965 word hy deur die kerk benoem op die Kommissie vir die Hersiening van die Afrikaanse Bybelvertaling, en toe daar mettertyd besluit is om oor te gaan tot ' $n$ nuwe vertaling uit die grondtale, word hy halftyds afgesonder om aan die projek deel te neem. Hy het 'n belangrike aandeel in die nuwe vertaling wat waarskynlik teen die einde van hierdie jaar afgehandel sal wees, en is tans vise-voorsitter van die Eindredaksie. [Die Nuwe Afrikaanse Bybelvertaling het intussen al verskyn.] Die Afrikaanse Studentebond het in 1977 aan hom saam met ander vertalers ' $n$ eretoekenning vir die bevordering van Afrikaans gemaak.

Op kultuurgebied was en is prof Oberholzer aktief betrokke as dienende offisier in die Voortrekkerbeweging, wat hom in 1979 vereer het met die toekenning van die Orde van die Fakkel vir buitengewone diens aan die Beweging. Hy is lewenslid van die FAK en SABRA, erelid van die voormalige Genootskap vir die Handhawing vir Afrikaans, assessorlid [tans volle lid] van die Suid-Afrikaanse Akademie vir Wetenskap en Kuns, stigterslid van die Ou-Testamentiese Werkgemeenskap, lid van die SA Kunsvereniging en van die Onderwyskommissie van die FAK. Naas lidmaatskap van skoolkomitees, beheerrade, die Raad van die Randse Afrikaanse Universiteit en tans van die Raad van die Pretoriase Technikon, het hy ' $n$ besondere band met die onderwys opgebou toe hy in 1954 ingewillig het om vir ' $n$ jaar verantwoordelikheid te aanvaar vir Afrikaans en Engels in st 8 tot 
matriek aan die Boksburgse tak van die Witwatersrandse Tegniese Kollege. [Prof Oberholzer dien tans as voorsitter van die Raad van die Pretoriase Technikon.]

Prof Oberholzer se publikasies sluit in mede-outeurskap van die handboek Bybelse Aardrykskunde, Oudheidkunde en Opgrawings, medewerking aan die Bybel met Verklarende Aantekeninge, die Suid-Afrikaanse Biografiese Woordeboek en verskillende ander bundels. Naas artikels op sy vakgebied en verskillende publikasies het hy 'n verskeidenheid van bydraes gelewer in koerantrubrieke en geleentheidspublikasies. [In 1986 verskyn 'n selfstandige publikasie uit sy pen, getitel Die Heidelbergse Kategismus: In vier teksuitgawes, met inleiding en teksvergelyking.]

Ooreenkomstig die bepalings vir die toekenning van die HCM Fourie-Erepenning, het die Kuratorium vir die Teologiese Opleiding van die Nederduitsch Hervormde Kerk van Afrika besluit om die penning vanjaar [1983] tydens die Algemene Kerkvergadering, aan prof JP Oberholzer toe te ken. Dit word gedoen op grond van die belangrike aandeel wat hy in die vertaling van die Bybel in Afrikaans het. Dat juis hierdie penning gedurende 1983, die jaar waarin ons die verskyning van die eerste Afrikaanse Bybel 50 jaar gelede herdenk, aan prof Oberholzer toegeken kan word, is van meer as gewone betekenis. Hierdie kosbare penning, uit goud geslaan, word ook toegeken as bekroning van sy groot diens aan die Kerk en vir sy besondere leiding, heldere formulering en optrede wat veral in geskrifte getuig van hoogstaande akademiese bekwaamheid en waardeur hy oor die afgelope jare die standpunt en houding van die Nederduitsch Hervormde Kerk help bestendig en uitgebou het. 